\title{
Syntactic Deconstruction of Beckett's Dramatic Text: A Transitivity Analysis of Waiting for Godot
}

\author{
Ijaz Asghar Bhatti ${ }^{1}$, Musarrat Azher ${ }^{1} \&$ Shahid Abbas $^{1}$ \\ ${ }^{1}$ Department of English, University of Sargodha, Sargodha, Pakistan \\ Correspondence: Musarrat Azher, Department of English, University of Sargodha, Pakistan. E-mail: \\ musarratazher@gmail.com
}

Received: April 3, 2019 Accepted: May 8, 2019 Online Published: June 27, 2019

doi:10.5539/ijel.v9n4p93 URL: https://doi.org/10.5539/ijel.v9n4p93

\begin{abstract}
This study examines the dominant elements of Transitivity (Ideational meaning) of Samuel Beckett's Waiting for Godot. The analysis of data was conducted by using computational tool, UAM Corpus Tool (UAMTC). The study has found that Beckett's dramatic text has a considerable amount of Material processes going on in the world of the play but these processes are less directed to a Goal and are even agentless too. The processes are also not spatially and temporally situated. The characters are out of time in Waiting for Godot (Esslin, 1980). The text is a linguistic paradox; lexically simple but structurally complex. The fragmented syntax of the play corresponds with the chaotic existence of man. The meaninglessness of human life has been conveyed through broken language. It is due to these qualities that the play is able to make a mark on the minds of its readers. The present study has explored of the possibility of reconciliation between literary and linguistic approach to the study of literary texts in general and modern drama in particular.
\end{abstract}

Keywords: transitivity analysis, material processes, waiting for Godot, meaninglessness of life

\section{Introduction and Background}

Samuel Beckett is considered to be a representative modern dramatist. His expression was flavored with the techniques of experimentation and invention because of which he is categorized as the "the last modernist". Ezra pound's renowned saying "making it new" is marked as the prime feature of modernism (Alexander, 1979, p. 19). Modernism as an umbrella term encompasses wide range of multi-faceted trends of the twentieth century such as "Symbolism", "Dadaism", "Expressionism", "Futurism" and all other movements centralized on the notion of practicing the techniques of "experimentation" and "unpredictability" (McDonald, 2006).

It becomes quite precarious to incorporate such diverse doctrines into the single faculty of modernism but apart from it, a concrete belief that it carves up are its cultural and social realizations of the contemporary age marked as "modern". Beckett, in 'Proust', described the ugly deceptive nature of the realist art as "the miserable statement of line and surface" and "the penny-a-line vulgarity of a literature of notations" (Chang, 2009, p. 247). The Modernists intended to make the reader befuddled by introducing certain new and intricate styles of writing and by disentangling themselves from the contemporary upper strata.

Samuel Beckett, in spite of diverse influences, had something of his own in his works (Pilling, 1994). In Eliot's words, I should say, his artistic genius and 'individual talent' surpassed all and established him as an intuition in literature. His radical works challenged and forever changed the concepts of literature and theatre. His works are a core part of introductory and advanced courses on literature around the world (Pattie, 2001). The study of literature remains incomplete without the study of Beckett. How strange it seems that in this age of objectivity, little attempts have been made to employ objective techniques of analysis of his texts. Matchless advances have been made in text analysis, stylistic and discourse analysis. The studies of Samuel Beckett's works lack linguistic touch. Linguistic analysis of Beckett's texts may open up new vistas and a range of objective interpretations which may lead to better understanding of his works with more solid empirical evidence otherwise his works will remain a riddle as ever (Cronin, 1999).

In the domain of linguistics, two main streams of schools have made marvelous achievements in the field of text analysis namely - Structuralism and Functionalism. The former is an evolved form of the Prague school of linguistics which held that language was a phenomenon having functional potentiality (Kirsten, 2002). More 
recently, Functionalism has come to be associated with the British linguist Michael Alexander Kirkwood Halliday and his disciples. Halliday and Hudson are considered to be the followers of J.R Firth and Malinowski who held that language is a socially dependent system to perform social functions (Sampson, 1986).

For Halliday, language is a resource for making meaning and grammar of a language is a source for creating meanings by means of wording, a lexico-grammatical approach to language. In this view, the text is the basic unit of language organized as discourse. The study of sentence is made in its discourse environment (Matthiessen, 1997). Systemic grammar studies sentence in a text within its own context, the central principle of systemic functional analysis. The proposed study is the application of systemic functional model of grammar to examine the process going on in Beckett's dramatic text. In other words, it has been envisaged to study Ideational (experiential) meanings or Transitivity of Samuel Beckett's Waiting for Godot.

The proposed study has been designed to investigate the linguistic manipulations in the dramatic world created by Samuel Beckett in Waiting for Godot. Systemic functional model of grammar has been purposefully selected for this study because it provides systematic means to empirically measure the functions performed by the sign (language) in the text.

\subsection{Statement of the Problem}

The dramatic texts of Samuel Beckett remained a mystery predominantly because of their linguistic compositions. Many critical interpretations of Beckett's works have been made throughout the last few decades but a very few considerable research works have appreciated the linguistic aspects of his dramatic texts. The present research has been designed to give a syntactic description of Waiting for Godot's linguistic composition using Transitivity system of clauses in the text. This study examined the system of Transitivity (Ideational/Experiential meanings) in individual clauses to explore the nature of process present in the text.

\subsection{Research Questions}

The present study is set out to answer the following research questions in studying elements of Transitivity in Beckett's play:

- What are the dominant elements of Transitivity in the text of Waiting for Godot?

- How Clauses and sub-types of clauses are interpreted in the system of Transitivity in the text of Waiting for Godot?

\subsection{Significance}

The research opens a new horizon to the study of literary texts of Samuel Beckett. It also highlights the novel dimension of his works. It provides some solid grounds to the more objective interpretation of the plays of Beckett ever known to Beckettonian studies. The research unfolds only one layer of the syntactic meanings of Beckett's play, further researches may also be conducted on Mood and Theme in his texts. A similar scheme of study may be applied to the other literary artists to draw more concrete meanings. The study has very widely ranging pedagogical implications in the learning and teaching of literature and language also. It bears vital significance for the students and teachers of English Language and Literature. The study is equally important for the syllabus designers working on teaching language through literature.

\section{Review of Literature}

Research in recent decades has focused on the literariness of language in everyday interactions such as in jokes, puns, advertisements, and newspaper headlines (Cook, 1994; Carter, 1999; Carter \& McCarthy, 2004; Kramsch \& Kramsch, 2000). Carter (1999, 2005), for example, explores how a cline of literariness can be explored on a continuum from literary to non-literary uses of language. For Carter, all texts can be analyzed on this cline by the presence or absence of certain linguistic and structural elements. For Williams (1998), such linguistic play is part of ordinary creative works like jokes and nursery rhymes but not in case of complicated texts like Waiting for Godot. Application of linguistic theory to explore the intricate literary text is highly called for. Eagleton (1983) sees literature as an ideological construct used to satisfy mainstream tastes and needs of a particular era and socio-political context. Similarly, Fowler (1986) sees an inseparable connection between the linguistic structures in literature and the socio-political context of its production and reception. In his SFL analysis of Shakespeare's King Lear, for example, Fowler shows how the interpersonal choices enacted in the play relate very closely to the type of relationships enacted among kings and their subjects in Elizabethan times. The newly combined field of cognitive poetics (a new form of literary criticism that applies the principles of cognitive science to the interpretation of literary texts) and linguistic analysis (e.g., Semino, 1997, 2005; Turner, 1991) holds the view that literary texts avail of the same linguistic and cognitive resources as non-literary texts. However, the 
innovative use of these resources by literary writers impact readers in sometimes startlingly creative ways.

Miall and Kuken $(1994,1998,2005)$, in order to explore the impact of foregrounding of specific patterns, took literary short stories by Virginia Woolf and Kate Mansfield and coded each phase of the texts for foregrounded features at the phonetic, grammatical, and semantic levels. They gave the texts to two selected types of university level readers, less exposed and more exposed to literature. However, they elicited several measures from readers such as reading times per segment and ratings for emotional response and surprise (the researchers use the term "strikingness"). Their results showed that both groups were responsive to the presence of systematic patterning of language in the texts (i.e., foregrounding) but that the more experienced readers rated the innovative texts higher for emotional impact when the foregrounding of specific patterns were innovative and new.

There are many other researches and reviews on one of the most influential and celebrated playwrights of the last century, Samuel Beckett. Foster (1989) applies an understanding of Zen Buddhism to the absurdity of Beckett, which is seen as an expression of deepest spiritual anguish. Kalb (1989) has given insight into specific problems of performing Becket's works. Armstrong (1990) explores the relationship between Beckett and his fellow Irish artists. Whereas, Harringfor (1991) has shown the influence of Becket's native culture on his art. Amiran (1993) has demonstrated how Beckett's works are not a failure of synthetic vision. Bryden (1993) has studied the evolving role of women in Beckett's works. Gordon (1996) has treated Beckett mildly as compared to Deirdre Bair. Beckett and Schneider (1998) have given an ample record to study Beckett's views about stage and theatre direction, Ohara and Gontarski (1997) have applauded Beckett for his masterful use of psychological sources, themes and narrative structure of Freud and Yung. JD O'Hara and Crontarski (1997) have examined the shift from philosophy to psychology.

Some scholars, however, have explored the linguistic dimensions of some of his plays. Carriere (2005) has studied the bilingualism of Beckett and it influence on his style in his later plays. She investigated his style with reference to All That Fall and Happy Days and established the influence of the mother tongue on Beckett's writing style. Sikorska (1994), has made a pragmatic study of the text of Endgame and found that the routine of talking of Beckett's characters enabled them to exert the force of their existence. Laws (1996) studied music and language in Beckett's works and revealed the patterns of phonological features to create music in his works.

Since the advent of the twenty-first century, use of computational tools to the study of linguistic features of text has been in excess and these tools have produced very useful objective knowledge. Researchers have explored a variety of areas taking the aid of UAMCT corpus tool Software. UAMCT is one of the most functional and productive tools to study layers of texts. Schulz (2008) uses UAMCT for analysis of verbal group in English and German newsgroup texts. Lozano (2009) used UAMCT software to tag Subject in finite sentences for such properties as syntax, number, animacy, information status and paradigmaticality. In order to combat learner problems, authentic learner data derived from UAM corpus tool can be employed to annotate word order errors with adverbs (Rankin, 2010) whereas Yang (2011) shows how appraisal theory can be utilized to drive writer's point home in English and Chinese crisis reports using engagement system in Appraisal Theory. Baklouti (2011) studies the impact of genre and disciplinary differences on structural choice with a focus on taxis in research articles abstract by incorporating UAM corpus tool software. In the same way, patterns of appraisal in texts and corpora can be visualized (Almuntairi, 2013). Fryer (2013) annotates a corpus of 100 research articles of approximately 700,000 words from five of world's famous general medical journals during the period of 19902010. A subsample of 164,000 words from that corpus was annotated for heteroglossic features with the support of model of Martin and White (2005) using UAM Corpus tool. The use of this software is more effective in recognizing heteroglossic engagement patterns in medical research articles than using manual techniques to analyze individual text or its segment (Fryer, 2013). The computational tool mentioned above has produced a significant data about different kinds of text but very rare application of these tools to the study of literary text and particularly to complicated text of Beckett's Waiting for Godot has been found; thus, leaving a gap and the present study is a humble attempt to fill this gap.

\subsection{Theoretical Framework}

Analytical method of investigation is adopted to study the Transitivity system in the text of Samuel Becket's Waiting for Godot, using computation tool, i.e., UAM Corpus Tool (UAMCT). This section adduces theoretical orientations of the present study. In this regard, a brief introduction of Systemic Functional Linguistics (SFL) model of Transitivity is outlined.

\subsection{SFL Model of Transitivity}

Theoretical source of Systemic Functional Linguistics (SFL) emerges out of functional approach to language. As 
opposed to other structural approaches which centralize the meanings with the combination of elements of language, SFL emphasizes social context as the generative factor in linguistic combinations. This approach accounts for the fact how language acts and is constrained by the social context.

Hallidian framework of functional grammar identifies three metafunctions of language i.e., Ideational, Interpersonal and Textual and these may be used as a potential instrument for the analysis of text. Textual function, as a metafunction, accounts for how language is used to produce text fit to carry message within a specific context. The success of this function depends on the users' linguistic competence to pack meaning into notation and then to churn them out. Interpersonal function underlies the participatory moves. Expressing his attitude and behaviour, the user attempts to influence the others' attitudes and behaviours. So, Interpersonal thematicity conveys interactional information with the help of some vocative items. Through Ideational function, the world is conceptualized purposefully. Ideational function may be called the content function of the language. The present study has explored this very function of Samuel Beckett's dramatic texts.

Transitivity may be called the mental transformations available in a text which, in turn, represent the encoding of experiential meanings through a systematic fusion of processes, participants, circumstances, experiences and notations. Transitivity analysis focuses on the functioning of transitivity constituents in a text. This analysis helps to identify the process type, specific action, event and the functional relationship of all the elements of transitivity. So, transitivity analysis may be a great support to define how the world is perceived, presented and explained by the participants involved in a discourse. Halliday (1979) identifies six types of process i.e., material, mental, verbal, behavioural, relational and existential.

The data are the text of Samuel Beckett's Waiting for Godot. The analysis of the text of the play relies on computational tool, UAMCT.

\section{Research Methodology}

\subsection{Data Collection}

In order to prepare the data in a form accessible for these tools, the data needed to be acquired in electronic form. Usually, the corpus software operates on .txt format files. Thus, the ideal format of soft form of the text in which data needed to be collected was .txt format. The whole text of the play was converted into PDF format and then it was converted into .txt format electronically.

After acquisition of the text in the required format, the next step was to edit it. The text of the play includes stage direction/meta-comments, etc. by the author, which were removed from the file. Even the names of the characters printed before each dialogue were removed from the text but the names of characters occurring within dialogues were not removed because they acted as significant elements of Transitivity as Participants. The remaining text prepared for processing through corpus software comprised dialogues among characters of the play.

\subsection{Data Analysis}

The corpus-based analysis of the text of Waiting for Godot was conducted through UAMCT.

\subsection{UAM Corpus Tool}

UAMCT is an online tool for language data analysis (available at http://www.wagsoft.com/CorpusTool/download.html). It was developed by, Mick O'Donnell, a renowned computational linguist. UAMCT is a tool that facilitates the linguistic coding of corpus material through the efficient prompting of the user for relevant categories. Features are defined and then the codes are assigned according to the hierarchy. These codings can then be statistically analysed, either using the built-in comparative statistics programms or by exporting the codings in a form readable by statistical packages. The following steps were followed to operate the software for analysis of the text;

i. Naming the files in a folder

ii. Specification of files to process the data

iii. Incorporation of files on Software tool to analyze

iv. After incorporation, the automatic annotation was done for the present study.

v. After this operation, the tool offered a choice of annotation schemes, Stanford Parse, SFL-Mood, SFL-Transitivity and SFL Theme. Keeping in view the aim of study, SFL-Transitivity was selected.

vi. The software analysed the text and produced an output file of annotated text. 
The analysed data in UAMCT is available statistically through another function named 'Explore'. Statistical search offers frequencies and significance tests for the results.

\section{Data Analysis and Interpretation}

This section describes the analysis and interpretation of data of Samuel Beckett's Waiting for Godot by applying UAMCT to explore the layers of Ideational meanings (Transitivity Analysis).

\subsection{Transitivity Analysis}

The annotated version of Waiting for Godot was put to analysis of Transitivity (Ideational) elements. It is important, for the sake of clarity, to present the coding scheme to analyse Transitivity. Coding scheme employed to analyse the texts under study is give below:

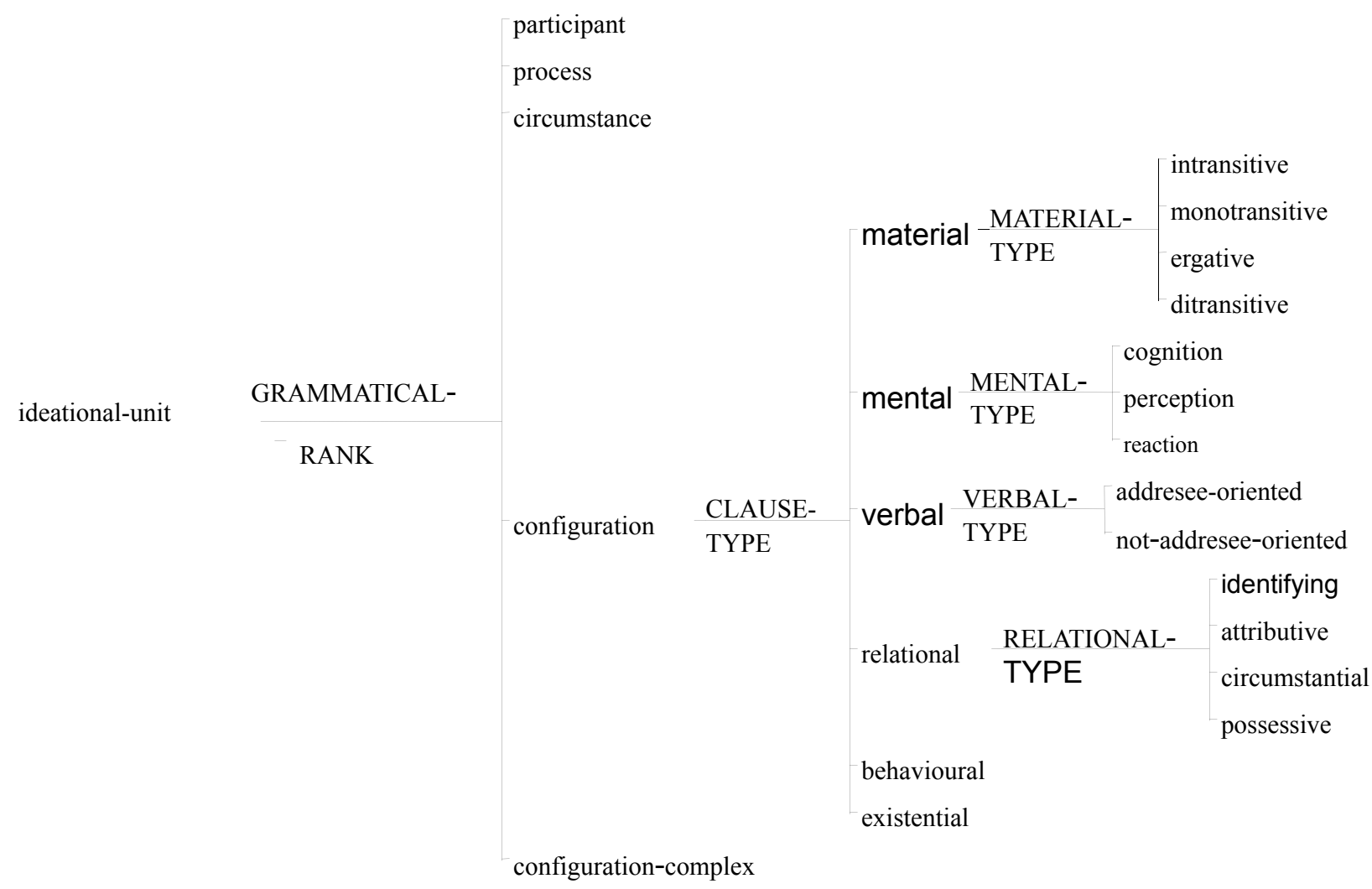

Figure 1. Coding schemes

Summary of the results is given below in the table: 
Table 1. Ideational/transitivity analysis vales

\begin{tabular}{lll}
\hline Project: & Final Analysis & \\
Counting: & Local & \\
Unit: & LayerF1: ideational-unit & \\
Date: & Sun Jul 20 18:47:36 2014 & \\
\hline Feature & $\mathbf{N}$ & Percent \\
GRAMMATICAL-RANK & $\mathbf{N}=\mathbf{9 8 9 1}$ & \\
\hline Participant & 3331 & $33.68 \%$ \\
Process & 2830 & $28.61 \%$ \\
Circumstance & 1055 & $10.67 \%$ \\
Configuration & 2675 & $27.04 \%$ \\
configuration-complex & 0 & $0.00 \%$ \\
CLAUSE-TYPE & $\mathbf{N}=\mathbf{2 4 7 8}$ & \\
Material & 1324 & $53.43 \%$ \\
Mental & 387 & $15.62 \%$ \\
Verbal & 170 & $6.86 \%$ \\
Relational & 553 & $22.32 \%$ \\
Behavioural & 10 & $0.40 \%$ \\
Existential & 34 & $1.37 \%$ \\
MATERIAL-TYPE & $\mathbf{N}=\mathbf{1 3 2 4}$ & \\
Intransitive & 539 & $40.71 \%$ \\
Monotransitive & 694 & $52.42 \%$ \\
Ergative & 0 & $0.00 \%$ \\
Ditransitive & 91 & $6.87 \%$ \\
MENTAL-TYPE & $\mathbf{N}=\mathbf{3 8 7}$ & \\
Cognition & 0 & $0.00 \%$ \\
Perception & 0 & $0.00 \%$ \\
Reaction & 0 & $0.00 \%$ \\
VERBAL-TYPE & $\mathbf{N = 1 7 0}$ & \\
addresee-oriented & 0 & $0.00 \%$ \\
not-addresee-oriented & 0 & $0.00 \%$ \\
RELATIONAL-TYPE & $\mathbf{N}=\mathbf{5 5 3}$ & $0.00 \%$ \\
Identifying & 0 & $89.38 \%$ \\
Attributive & 494 & $0.00 \%$ \\
Circumstantial & 0 & $10.62 \%$ \\
Possessive & 59 & \\
\hline
\end{tabular}

The table is represented diagrammatically in the Figure for more clarity below:

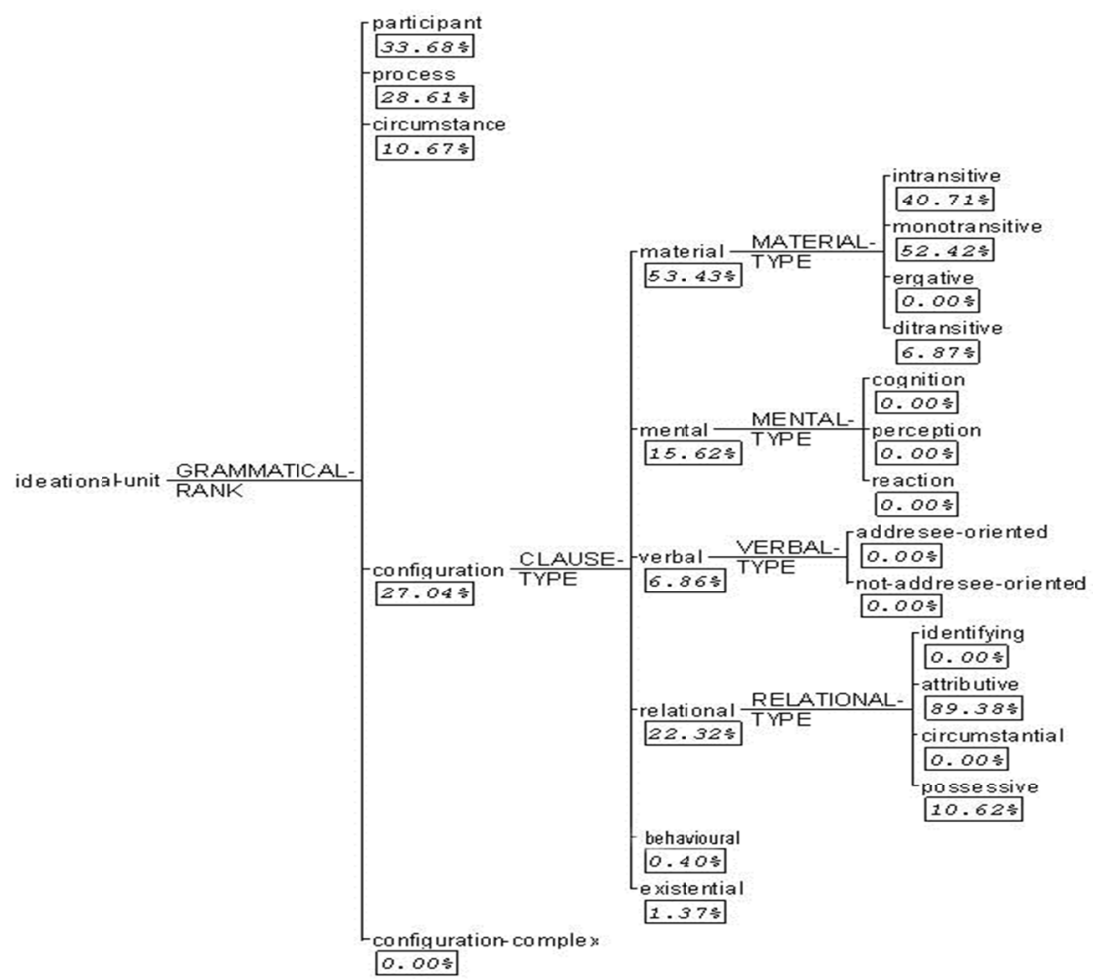

Figure 2. Diagrammatical representation of table 
The data analysis tool generated three main types of information about the Transitivity of Waiting for Godot as indicated above:

\section{Grammatical Rank}

II. Clause Type (Process in the clause)

III. Subtypes of each clause.

\section{Grammatical Rank}

The tool identifies five ranks of grammatical units:

- Participant

- Process

- Circumstance

- Configuration

- Configuration-Complex

The total numbers of grammatical units in the analysed text are 9891 . Out of these 9891 grammatical units, there are 3331 (33.68\%) Participants, 2830 (28.61\%) Processes, 1055 (10.67\%) Circumstances, 2675 (27.04\%) Configurations and no Configuration Complexes. The relative frequency of Grammatical Ranks is given in the Figure below:

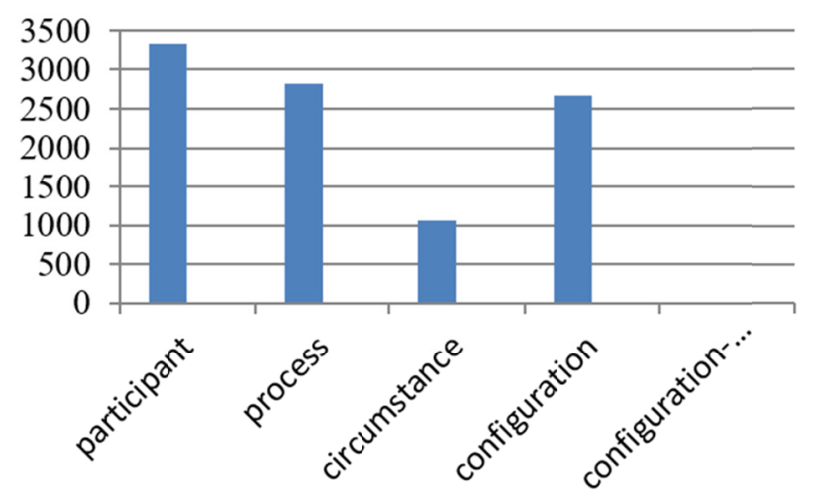

Figure 3. Frequencies of grammatical ranks

\subsection{Participants}

Participants in a clause include; Actor and Goal or the doer of the action, entailed in the Process and Receiver of the action. The above Table and Fig shows that Processes or actions in the whole text of Waiting for Godot are 2830; whereas, the total number of Participants is 3331. Normally, the number of Participants is far greater than the number of Processes contained in an English text which is due to the fact that most of the verbs are transitive and take one doer and one receiver of the action contained in the verbs. Some verbs are ditransitive and take two objects in addition to a subject (Martin, Matthias, \& Painter. 1997). The readings of data generated by UAMCT signify that the number of Participants is quite less. Participants are only 5.07\% greater than the total number of Processes in the text of Waiting for Godot.

UMACT did not analyze most of the subjectless clauses and if those were included, the total number of Processes could easily exceed the number of Participants in the text which is unusual in normal English language interaction. This feature of the text of Waiting for Godot entails directionlessness of the Participants; their actions are less Goal oriented.

\subsection{Process}

The next Grammatical Rank is Process and the analysis shows that there are 2830 Processes in the text. This number of Processes in a text is closer to the total number of clauses. As discussed in the last section that the total number of Processes in the text is significantly high as compared to rest of the features of the text. The detailed discussion on this very feature of the text is presented in the section on clause type. 


\subsection{Circumstance}

Circumstances augment the Configuration of Process and Participants in a clause through the semantic relations of projection and expansion like location, cause, extent, manner, etc. Circumstances of a clause explain and clarify the process contained in it (Matthiessen, Tervya, Marin, \& Lam, 2010). With the addition of Circumstances in a text, meanings and relation between Process and Participants is collaborated. Circumstance imparts clarity of understanding to the action contained in a text. The total instances of Circumstances in Waiting for Godot are 1055 (10.67\%) of the total Grammatical Ranks. Circumstances have a direct relationship with Participants and Processes in a clause. The figures in above table show that there is a relatively reduced number of Circumstances in the text of Waiting for Godot. Circumstances help identifying and fixing things in a text. But a low number of Circumstances in a text indicates low definiteness. Circumstances normally tell how, when, where, why, how much, how frequent an action is performed or received by the Participants (Martin, Mathessan, \& Painter, 1997).

\subsection{Configuration}

Configuration is that element of Transitivity which is a combination of smaller elements like Circumstances, Process and Goal except the Actor and the main Process (Halliday, 2010).

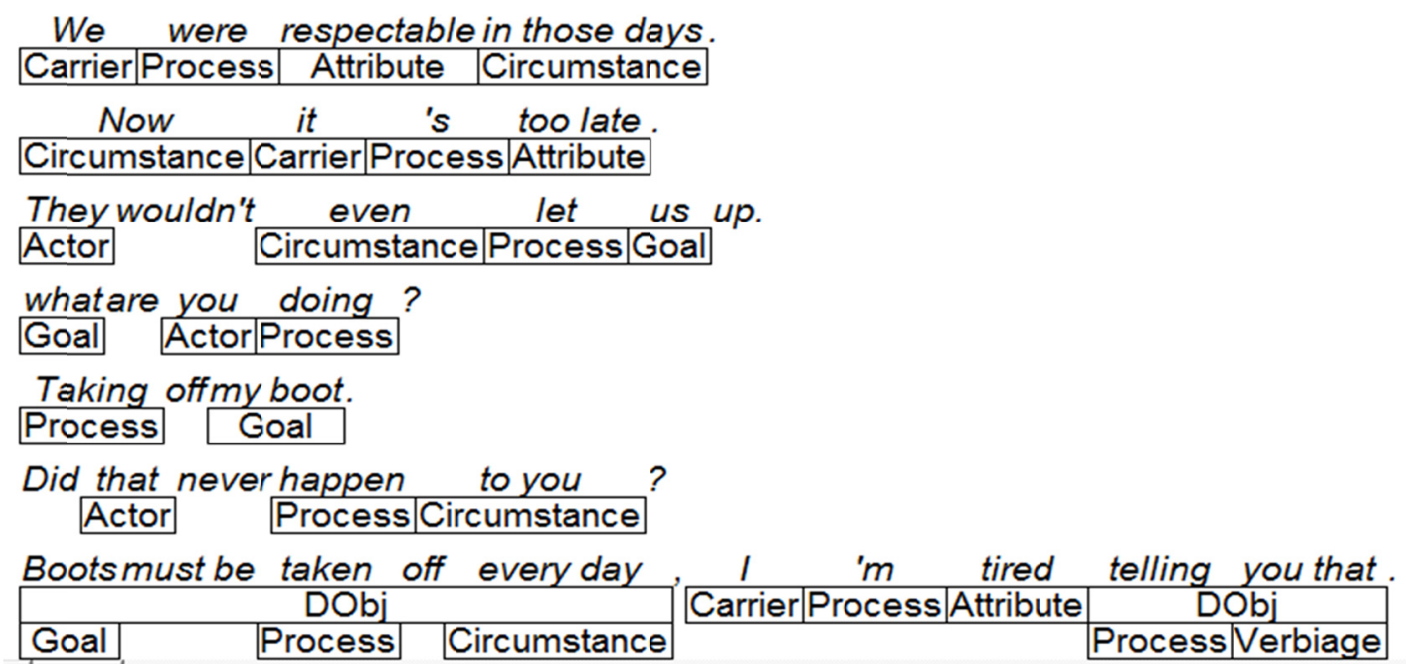

Figure 4. Configuration

There are 2675 (27.04\%) instances of Configuration in the text analyzed.

Configuration has two contradictory functions in a text. It either complicates or elaborates a text.

Clause Types

The next main chunk of information generated through the data analysis is

The six types of clauses are:

- Material

- Mental

- Verbal

- Relational

- Behavioural

- Existential

The frequency count of relative occurrences of clause types is given in the figure below: 


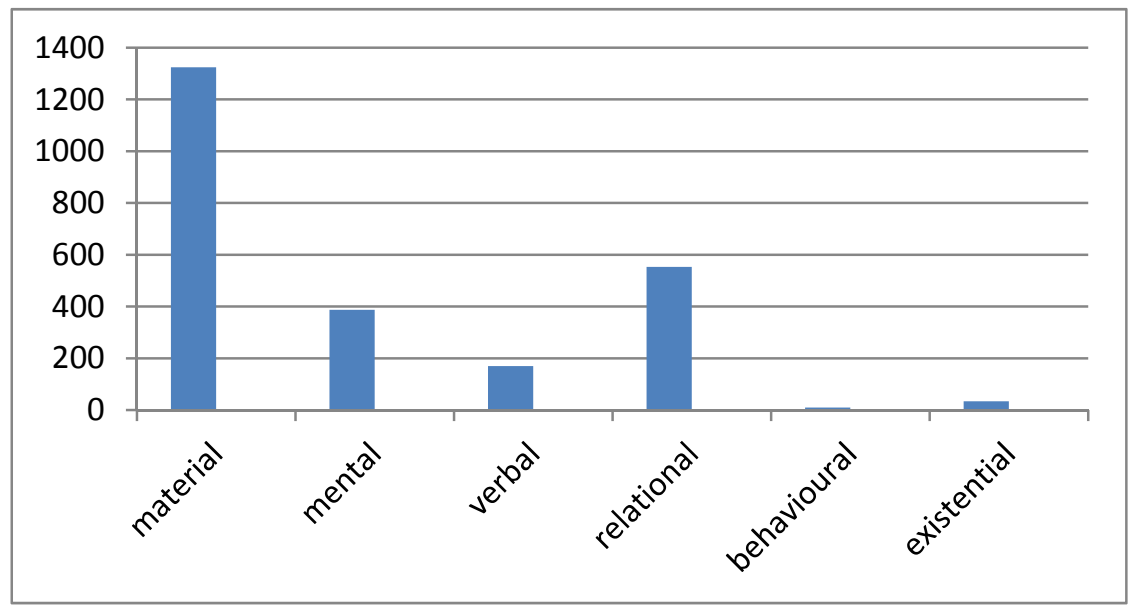

Figure 5. Frequencies of clause types

\subsubsection{Material}

Material clauses contrive doings and happening and cover both concrete and abstract processes (Martin, Matthiessem, \& Painter, 1997). Material clauses are the most frequent occurring element of Transitivity in naturally occurring languages. In the text of Waiting for Godot, the total number of Material clauses is 1324 $(53.43 \%)$. Though this number is quite significant as compared to the other types of clauses yet the real picture will emerge after the analysis of sub-types of Material clauses.

\subsubsection{Mental}

Mental clauses construe a person involved in conscious proceedings like processes of:

\section{- Perception}

- Cognition

- Reaction

- $\quad$ Affection etc. (Martin, Matthiessen, \& Painter, 1997).

Data analysis indicates that there are $387(15.32 \%)$ Mental clauses in the text. Mental clauses are one of the three main types of processes in a language. The value of Mental clauses is quite significant but less than the expected frequency of these clauses in an Existential text. It was expected that, in Waiting for Godot, Mental clauses could be more frequent as compared to normal texts.

\subsubsection{Relational}

These clauses are a generalized notion of copula sort of construction and construe being and have four sub-types:

- Identifying (e.g., Ali is captain)

- $\quad$ Attributive (e.g., He is energetic)

- Circumstantial (e.g., He is out of class)

- $\quad$ Possessive (e.g., I have three cars) (Martin, Matthiessen, \& Painter, 1997)

The total number of Relational clauses is $553(22.32 \%)$ out of 2478 . This number is relatively quite normal. Relational clauses bring definiteness in the text. These clauses place and recognize things with reference to internal and external context. In other words, Relational clauses identify things with reference to the external world. Frequency of these clauses does have a cohesive function in a text (Hassan, 1989; Martin, 1992). This very feature of Waiting for Godot; however, does not correspond with the proponents Existentialism.

\subsubsection{Verbal}

Verbal clauses involve the process of saying like asking, offering, commanding, stating etc. the examples of verbal clauses are:

She asked a question

They said that he was happy (Martin, Matthiessen, \& Paniter, 1997). 
There is a small number of Verbal clauses in Waiting for Godot. As indicated in Table 1, the total number of verbal is $170(6.86 \%)$ out of 2478 clauses. This number is relatively low as compared to naturally occurring texts. The texts having low frequency of Verbal clauses indicate that the Participants of the Process remain aloof and isolated; they seem to have no one as their interlocutors. People involved in normal communicative event do have interlocutors; the number and involvement of interlocutors is reflected through the Verbal processes. Low frequency of Verbal clauses signifies that the Participants are engaged in audienceless communication which renders them to isolation. Isolation also corresponds with the essence of Existentialism.

\subsubsection{Behavioural}

Behavioural clauses construe human behavior. This type of clauses exists between Material and Mental/Verbal ones. There are two types of Behavioral clauses, Psychological and Social e.g.

He is shivering (psychological).

She is dancing (social) (Martin, Mattheissen, \& Painter, 1997).

The number of Behavioral clauses in the text is surprisingly low as identified by UAMCT analysis. Out of 2478 clauses, there are only $10(0.40 \%)$. This number is significantly low. A low number of Behavioural clauses in a text signifies a world deprived of human activity, particularly Social type. Social behaviours are always given and contradict with the basic postulates of Existentialism. This feature of Waiting for Godot indicates that the world presented in the play lacks social dimension and the participants interact but socially. This deficiency of social behaviour represents unstructured social existence of human beings. Again, this feature of Waiting for Godot corresponds with the Existential mode of human existence.

\subsubsection{Existential}

Existential clauses construe state of being e.g.,

There will be a storm (Martin, Mathiessen, \& Painter, 1997).

Table shows that the number of Existential clauses like behavioural clauses is also very low. It ranges to 34 $(1.37 \%)$ in the total clauses 2478 . The low number of Existential clauses signifies the low density of state of being but it is important to note that Existentialists talk about being of human existence and not the existence of everything around him in the external world (Cohn, 1980). However, this feature of the test points out to the fact of isolation; it may further indicate the existence of man in a spatially and temporally unidentifiable world. The absence of existence of identified creatures and features of external world maintain an environment of solitude in a text (Hassan, 1989).

\subsection{Subcategories of Clause-Type}

As mentioned in the Process section, the actual picture of Experimental meanings of Waiting for Godot could be clarified after the discussion of sub-types of main clauses. This section deals with the subcategories of elements of Transitivity of main six clause types.

\subsubsection{Subcategories of Material Clauses}

The above table shows that there are four subcategories of Material clauses:

- Intransitive

- Monotransitive

- Ditransitive

- $\quad$ Ergative

The values of relative frequency of subcategories of Material clauses are given in the figure below: 


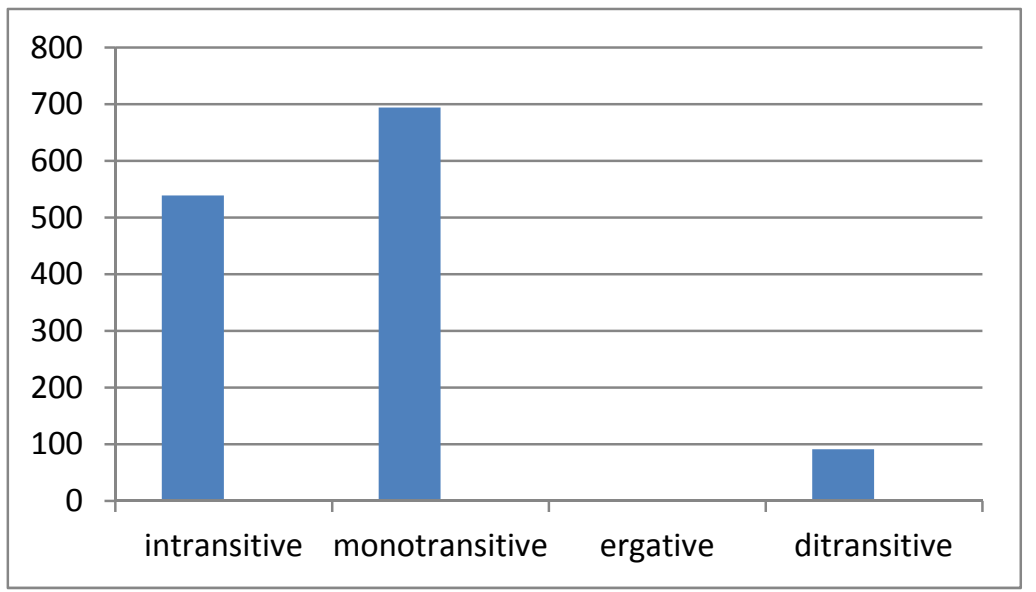

Figure 6. Frequencies of material subcategories

\subsubsection{Intransitive}

As indicated in Table 1, there are 539 (40.71\%) Intransitive processes in total 1324 of Material processes. This number is significantly high as compared to normal interactive text. This feature also corresponds with the low number of Participants as discussed in the earlier section about the elements of Transitivity in Grammatical Ranks. Such features normally indicate directionless actions in a text (Hassan, 1989). This is yet another aspect of the features of Waiting for Godot which conforms with the characteristics of Existentialism.

\subsubsection{Monotransitive}

Monotransitive clauses exhibit such material action in which the action contained in clause is passed on to a single Goal (receiver of the action). There are 694 (52.42\%) Monotransitive processes in the text of Waiting for Godot. As compared to normal interactive texts, this number is fairly low. This feature of the text shows that less number of material actions is being directed to the identified Goals. Most of the Processes in Waiting for Godot are Goalless and this feature of the text of Waiting for Godot corresponds with purposelessness, a major tenant of Existentialism, and it is also in line with the results mentioned in section 4.2.1.1 of this chapter.

\subsubsection{Ditransitive}

This subcategory of Material processes requires two Goals: one being Goal and the other Beneficiary. The values of these processes are also relatively low as compared to their frequency in normal texts in English. The number of ditransitive Material clauses is as low as $91(6.87 \%)$ out of 1324 . The frequency of Monotransitive and Ditransitive Material processes corresponds with the high frequency of Intransitive Material processes and imparts the same impact of frequent directionless and purposeless actions. Existentialists also believe in the absence of pre-existent metaphysical reality (Esslin, 1980). So, man's actions are left with no parameter to determine their direction.

\subsection{Subcategory of Mental Clauses}

Mental clauses are the next main category of clauses. Subcategories of Mental clauses include three types. Our analytical tool, UAMCT, does not identify the frequency of these subcategories separately. It is only due to the fact that Mental clauses appear in a smaller number. This aspect has been identified as deficiency of the tool applied to the study of Transitivity. Similar is the case with Verbal and Behavioural clauses sub-types.

\subsection{Subcategory of Referential Clauses}

Below figure shows relative frequencies of the subcategories of Relational clause type. 


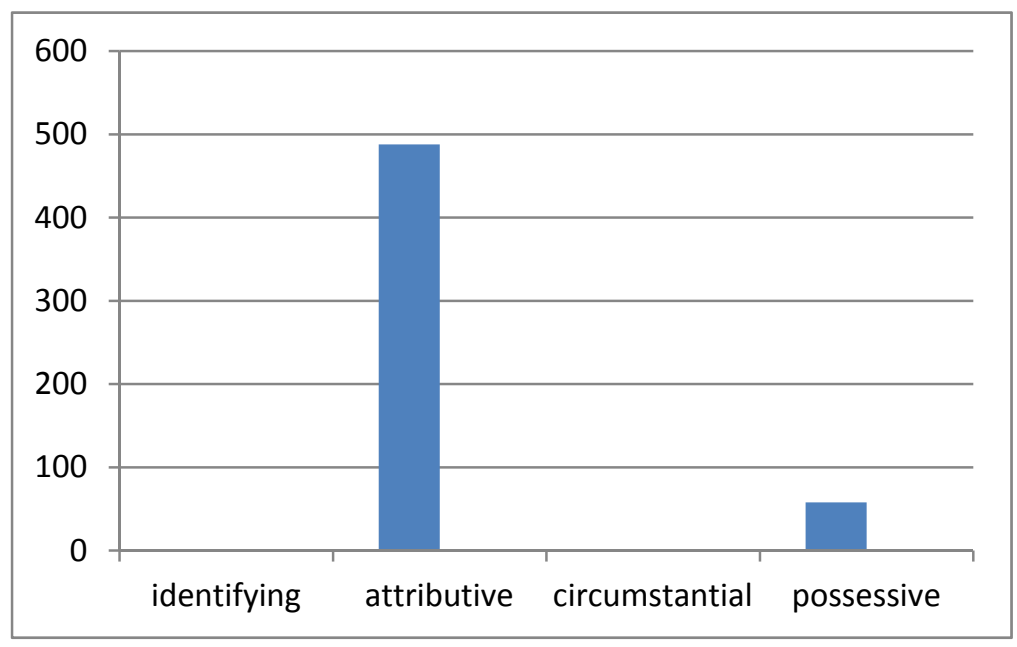

Figure 7. Frequencies of relational subcategories

Out of four sub-types of Relational clause, there are 494 (89.38\%) Attributive and just 59 (10.62\%) Possessive clauses but the tool identifies no Identifying and Circumstantial clauses in the text of Waiting for Godot. A very high number of Attributive clauses in a text indicate that the Participants in the text are engaged in identifying the world around them by attributing them some characteristic. If there were more Identifying type of Referential clauses, it would suggest definiteness and familiarity of the world around. The high frequency of Attributive clauses signifies that the identity of the world around is not given but is being constructed through the seemingly definite attributes of the objects of the world presented in the text.

\section{Conclusion}

The findings and summary of results made in the present study have been presented in this section.

In the pursuit to understand Beckett's dramatic text, computational tool, UAMCT has been employed to seek answers to the following research questions:

1) What are the dominant elements of Transitivity in the text of Waiting for Godot?

2) How clauses and sub-types of clauses are interpreted in the system of Transitivity in the text of Waiting for Godot?

For each question, the findings made from analysis of the data are reported and then these findings have been discussed. The summary of the findings to these questions is described below.

\subsection{Elements of Transitivity}

The analytical tool generated information about elements of Transitivity in three main categories i.e., Grammatical Ranks, six main Clause Types and Sub-types of main clauses.

The total numbers of grammatical units in the text are 9891 . Out of these 9891 grammatical units, there are 3331 (33.68\%) Participants, 2830 (28.61\%) Processes, 1055 (10.67\%) Circumstances, 2675 (27.04\%) Configurations and no Configuration Complexes.

The text of Waiting for Godot represents such Ideational world which has comparatively high Processes as compared to the number of Participants. Even the number of Circumstances is also low. These proportions of Grammatical Ranks signify Actorless and Goalless clauses in the text. Most of the actions are not directed to any Goal. The world of Waiting for Godot represents actions but directionless. The function of Circumstance is to give spatial and temporal identity to the Process and Participants; they become more definite and identifiable in their context. Moreover, a relatively small number of Circumstances in the play also reveal that the actions and activities going on in it are less spatially and temporally oriented (Martin, Matthiessem, \& Painter 1997). These features of Transitivity in the play develop a theme of 'Alienation' to interpret the concept of Existentialism.

The most significant information on elements of Transitivity is contained in the analysis of its Clause types and sub-types. Three Clause types, like Material, Relational and Mental, have high frequency values. Material clauses are the most frequently occurring action in Waiting for Godot (i.e., 53.46\%). This shows that some sort of concrete or abstract actions are being carried out in the world of Waiting for Godot. It is an important finding 
about the play because it resembles with the feature of a normal human world of action and activity (Martin, Matthiessem, \& Painter, 1997). The Analysis of the Sub-types of Material clauses indicates that there is a high number of Intransitive Material processes (40.71\%) which are directed to no Goal. The value of Monotransitive processes is $52.42 \%$ which statistically appears to be significant but linguistically it is quite low because most of the Material processes are Transitive than being Intransitive (40.71\%). The reading of Ditransitive Material processes is as low as $6.87 \%$. Due to this low number of Monotransitive and Ditransitive Material processes, it is evident that the actions going on in Waiting for Godot are Goalless and lead to creation of a directionless and lost world. The findings of the analysis of Material processes correspond with the findings of the analysis of Grammatical Ranks earlier in this section and establish the themes of 'Alienation' and 'directionlessness'.

The frequency of Relational clauses is $22.32 \%$ in the text of Waiting for Godot which is relatively high as compared to the rest of the clause types except Material clauses. These clauses have an identifying function which is realized through 'being' construction of grammar. It is important to note that out of four sub-types of Relational clause, there are 494 (89.38\%) Attributive and just 59 (10.62\%) Possessive clauses. There is not even a single instance of Identifying and Circumstantial clause type of Relational clause in Waiting for Godot. A very high number of Attributive clauses in a text indicate that the Participants in the text identify the world around them by attributing some characteristics to them. The high frequency of Attributive clauses reveals that the identity of the world around is not given or preexistent but is being constructed through the speculative attributes of the objects of the world presented in the texts.

The frequency of Mental process is $15.62 \%$ in Waiting for Godot. It shows that the Participants in the text are involved in a mental activity and do have a potential of thought. The value of Verbal, Behavioural and Existential clauses is $6.86 \%, 0.40 \%$ and $1.37 \%$ respectively in Waiting for Godot. This value of these clause types is very low as compared to a normal interactive text of a drama. This low value of these three main elements of Transitivity indicates an imbalanced world.

The results and findings of the present study may be summarized as: the dominant elements of Transitivity in Waiting for Godot are the Processes with low number of Participants, Material clauses and statistically significant number of Intransitive Material processes. Relational clauses are another prominent feature of Beckett's dramatic texts with significantly high number Attributive Relational clauses. The text has a very scanty number of Verbal, Behavioural and Existential processes in it. The analysis of these features of Transitivity constructs the themes of Existentialism, i.e., Directionlessness, Alienation, Ambivalence and Vagueness.

\section{References}

Alexander, M. (1979). The Poetic Achievement of Ezra Pound. Barkeley \& Los Angeles: University of California Press.

Amiran, E. (1993). Wandering and Home: Beckett's Metaphysical Narrative. New York: Pennsylvania State University Press.

Armstrong, G. S. (1990). Samuel Beckett, W.B. Yeats and Jack Yeats: Images and Words. New York: Armstrong Bucknell University Press.

Bryden, M. (ed). (1998). Samuel Beckett and Music. Oxford: Clarendon Press. https://doi.org/10.1007/978-1-349-26538-1

Carriere, J. F. (2005). Samuel Beckett and bilingualism: How the return to English influences later writing style and gender roles in All that fall and Happy days. Unpublished Doctoral Thesis, Louisiana State University.

Carter. R. (1999). Investigating English discourse: Language, literacy and literature. London: Routledge.

Carter, R. (2005). Is there a literary language? In S. Goodman \& K. O'Halloran (Eds.), The art of English: Literary creativity (pp. 80-86). New York: Palgrave MacMillan.

Carter, R., \& McCarthy, M. (2004). Talking, creating: Interactional language, creativity, and context. Applied Linguistics, 25(1), 62-88. https://doi.org/10.1093/applin/25.1.62

Chang, P.-J. (2009). A Unity of Disunity: Ambivalence toward Modernity in Marcel Proust's Swann's Way. Feng Chia Journal of Humanities and Social Sciences, 228-253.

Cohn, R. (1973). Back to Beckett. New Jersey: Princeton University Press.

Cohn, R. (2001). A Beckett Canon. Michigan: University of Michigan Press. https://doi.org/10.3998/mpub.15933

Cook, G. (1994). Discourse approach to literature. Oxford: Oxford University Press.

Cronin, A. (1999). Samuel Beckett: The Last Modernist. New York: De Capo Press. 
Eagleton, T. (1983). Literary theory. Cambridge: Blackwell.

Esslin, M. (1964). The theatre of the absurd. London: Butler and Tanner.

Esslin, M. (ed.). (1980). Samuel Beckett: Twentieth Century Views. New Dehli: Prentice-Hall.

Foster, P. (1989). Beckett and Zen. Beckett and Zen: A Study of Dilemma in the Novels of Samuel Beckett. New York: Wisdom Publications.

Fowler, R. (1986). Linguistic criticism. Oxford: Oxford University Press.

García, G. R. (2011). A corpus-based grammatical analysis of modality in the writing of Spanish university students of English. Proceedings of ASYRAS. 2nd Conference of Young Researchers on Anglophone Studies. University of Salamanca, 6th-8th October 2011.

Gontarsk, S. E. (1985). The Intent of Undoing in Samuel Beckett's Texts. New York: Indiana University Press.

Gordon, L. G. (1996). The World of Samuel Beckett. New York: Yale University Press.

Halliday, M. A. K. (1969). Linguistic function and literary style: An inquiry into the language of William Golding's the inheritors. In C. Seymour (Ed.), Literary style: A symposium (pp. 362-400). London: Oxford University Press.

Kramsch, C., \& Kramsch, O. (2000). The avatars of literature in language study. Modern Language Journal, 84, 533-573. https://doi.org/10.1111/0026-7902.00087

Laws, C. (1996). Music and language in the works of Beckett. Unpublished Doctoral Thesis, University of York.

Martin, C., \& Rothery. (1987). Social processes in education: A reply to Sawyer and Watson (and others). In I. Reid (Ed.), The place of genre in learning: Current debates (pp. 58-82). Center for studies in literary education: Deakin University Press.

Martin, J., \& White, P. (2005). The language of evaluation: Appraisal in English. London: Palgrave. https://doi.org/10.1057/9780230511910

Mary, B. (1993). Women in Samuel Beckett's Prose \& Drama. Macmillan.

McDonald, R. (2006). The Cambrige Introduction to Samuel Beckett. New York: Cambridge University Press, https://doi.org/10.1017/CBO9780511607417

Miall, D. S., \& Kuiken, D. (1994). Foregrounding, defamiliarization and affect: Response to literary stories. Poetics, 22, 389-407. https://doi.org/10.1016/0304-422X(94)00011-5

Miall, D. S., \& Kuiken, D. (1998). The form of reading: empirical studies of literariness. Poetics, 25, 327-341. https://doi.org/10.1016/S0304-422X(98)90003-1

Miall, D. S., \& Kuiken, D. (2005). The form of reading: empirical studies of literariness. In S. Goodman \& K. O'Halloran (Eds.), The art of English: Literary creativity (pp. 443-450). New York: Palgrave MacMillan.

Pattie, D. (2009). Coming out of the Dark: Beckett's TV plays. Journal of Beckett Studies, 18(1-2), 123-135. https://doi.org/10.3366/E0309520709000314

Semino, E. (1997). Language and world creation in poems and other texts. London: Longman.

Sikorska, L. (1994). The language of entropy: A pragma-dramatic analysis of Beckett's Endgame. Studia anglica posnaneinsia, XXVIII, 195-208.

Stepheson, R. J., \& Harmon, D. E. (1998). The Insanity of Samuel Beckett's Art. New York: Paintbrush Press.

Weisberg, D. (2000). Chronicles of Disorder: Samuel Beckett and the cultural politics of the modern novel. Albany: State University of New York Press.

Williams, G. (1998). Children entering literate worlds: Perspectives from the study of textual practices. In F. Christie \& R. Misson (Eds.), Literacy and schooling (pp. 18-47). New York: Routledge.

\section{Copyrights}

Copyright for this article is retained by the author, with first publication rights granted to the journal.

This is an open-access article distributed under the terms and conditions of the Creative Commons Attribution license (http://creativecommons.org/licenses/by/4.0/). 